\title{
Tüketim Kültürü ve Sosyal Medya Bağlamında Trendyol Black Friday Reklamlarının Analizi
}

\author{
Analysis of Trendyol Black Friday Ads in the Context of Consumption Culture and Social Media
}

Duygu Ünalan, Dr. Öğr. Üyesi, Niğde Ömer Halisdemir Üniversitesi İletişim Fakültesi, E-posta: duyguunalan85@gmail.com

https://doi.org/10.47998/ikad.815429

\author{
Anahtar Kelimeler: \\ Yeni İletişim \\ Teknolojileri, \\ Sosyal Medya, \\ Tüketim, \\ Tüketim Kültürü, \\ Reklam.
}

\section{Keywords:}

New

Communication

Technologies,

Social Media,

Consumption,

Consumer Culture,

Advertising.

\section{$\ddot{\mathbf{O} z}$}

Tüketim, insanoğlunun var olduğu günden beri yaşamın önemli bir parçasıdır. İnsanlar varlıklarını sürdürmek, temel dürtülerini doyuma ulaştırmak için belirli nesneleri ya da ürünleri tüketmek zorundadırlar. Tüketim, endüstriyel gelişmelerle birlikte seri üretim yöntemlerinin bir sonucu olarak fordist dönemde standart duruma gelmiş ve bu dönemle birlikte kitlesel bir tüketim anlayışı ortaya çıkmıştır. Söz konusu kitlesel tüketim, tüketim kültürünün de doğuşunu beraberinde getirmiștir. Ortaya çıktığı günden beri tüketim kültürü, kitle iletişim araçları aracılığıyla yayılmış ve insanlar tüketime teşvik edilmiştir. 20. yüzyılda yaşanan teknolojik gelişmeler, reklamcılık faaliyetleri için yeni bir ortam olan sosyal medya ortamlarını ortaya çıkarmış, böylece tüketim kültürü de kendisini yeniden üretecek yeni ve daha aktif bir mecraya kavuşmuştur. Bu noktadan hareketle bu çalışmada sosyal medya ve tüketim kültürü ilişkisi bağlamında Trendyol'un Black Friday günlerinde (25-29 Kasım 2019) sosyal medya ortamlarında yayımladı̆̆ı reklamların analizinin yapılması amaçlanmıştır. Değerlendirmede günümüzde sanal mağazalar ve sosyal medya ortamlarının tüketim kültürünün devamlılığını sağlayan önemli mecralar olduğu sonucuna varılmıştır.

\section{Abstract}

Consumption has been an important part of life since the day human beings existed. People must consume certain objects or products in order to maintain their existence and to satisfy their basic impulses. Consumption has become the standard in the fordist period as a result of mass production methods together with industrial developments and a mass consumption understanding has emerged with this period. The mass consumption brought about the emergence of the consumption culture. Since its inception, the culture of consumption has spread through mass media and people have been encouraged to consume. Technological developments in the 20th century have created social media, which is a new medium for advertising activities, so that the consumer culture has gained a new and more active medium to reproduce itself. From this point of view, in this study, it was aimed to analyze the advertisements published by Trendyol on social media on Black Friday (25-29 November 2019) in the context of the relationship between social media and consumption culture. In the evaluation, it was concluded that virtual stores and social media environments are important channels that ensure the continuity of consumption culture. 


\section{Giriș}

20. yüzyılda iletişim teknolojilerinde yaşanan gelişmeler, insan yaşamına damga vurmuş̧tur. Söz konusu yeni teknolojiler, daha önce geliştirilen tekniklerin bir kombinasyonu olarak karşımıza çıkmaktadır. Bu teknolojiler ve yeni iletişim teknolojileri/ yeni medya sayesinde hız artmış, coğrafi ve demografik kapsama alanı genişlemiş ve erişim alanı büyümüştür (Aykurt ve Şeşen, 2017: 6).

Son yıllarda web bloglar, sosyal ağlar ve video paylaşım platformları gibi kullanıcı odaklı teknolojilere yönelinmiştir. Söz konusu bu sosyal teknolojiler, sosyal medya olarak aynı şekilde etiketlenmiş, kullanılan içerikte, küresel toplulukta ve tüketici görüşlerinin yayınlanmasında bir devrim yaratmıştır.

Dijital teknolojilerin gelişmesine kadar olan sürede geleneksel kitle iletişim araçları insan yaşamında önemli bir etkiye sahiptir. Ancak günümüzde dijital mecra ve yöntemler aracılığıyla hedef kitlelere ulaşmak çok daha kolay hale gelmiştir. Günümüzde bu dijital kitlesel kanalların başında sosyal medya gelmektedir. Sosyal medya, uzam ve zaman sınırını aşıp, hızlı ve anlık paylaşım olanağı sunarak büyük kitleleri basit ve maliyetsiz bir şekilde örgütleyebilmektedir (Doğan, 2019: 423).

Webteknolojilerive sosyal medya ortamlarıanlık iletişim, sınırsızlık, erişimkolaylığı, hızlı örgütlenme vb. olanaklar getirmesinin yanı sıra bireylerin tüketim alışkanlıklarını da değiştirmiştir. İnternet teknolojilerinin getirdiği olanaklarla web üzerinden satış yapılabilir hale gelmiş, bu da tüketim kültürüne yeni bir boyut kazandırmıştır. Bununla birlikte reklam verenler de yeni ve geleneksel kitle iletişim araçlarından daha geniş bir mecrada reklam yapabilir duruma gelmişlerdir. Öyle ki sosyal medya mecraları yeni tüketici kuşağın yoğun olarak yer aldığı ortamlar olarak reklam verenler açısından hedef kitleye ulaşma noktasında önemli bir alandır. Bu bağlamda çalışmada, sosyal medya ve tüketim kültürü ilişkisi bağlamında Trendyol'un Black Friday günlerine (25-29 Kasım 2019) sosyal medya ortamlarında yayımladığı reklamların analizinin yapılması amaçlanmıştır.

\section{Yeni İletişim Teknolojileri ve Sosyal Medya}

1990'ların başında, uygarlık tarihinde benzeri görülmemiş bir teknolojik yenilenme dönemi başlamıştır. 1970'li yıllardan itibaren bilgisayar, telekomünikasyon sistemlerinde önemli bir dönüşüme yol açmış ve teknolojik bir sıçrama yaşanmıştır. Bu sıçrama, iletişim teknolojilerinde büyük bir dönüşüm sürecinin başlamasının altında yatan en önemli faktördür. Bilgisayarın diğer iletişim araçlarının yapısına girmesi ve onları desteklemesi yeni iletişim teknolojilerini ortaya çıkarmıştır (Çakır, 2004: 169).

Yeni iletişim teknolojilerinin temeli ARPANET olarak adlandırılan ilk internet teknolojilerine dayanmaktadır. Teknik olarak interneti dünya çapındaki milyarlarca kullanıcıya standart internet protokol takımları (TCP/IP) aracılığıyla hizmet veren, birbirine bağlı küresel bilgisayar ağları sistemi olarak tanımlamak mümkündür. İnternet, bilgiyi saklama, paylaşma ve ona kolayca ulaşma amacı ile ortaya çıkmış ve gelişmiş bir sistemdir. İnternet, ortaya çıktığı andan itibaren bu platform üzerinde gerçekleştirilen 
çalışma şekilleri, yaklaşımları, kullanım amaçlarının değişmesi ve doğrultusunda değişip gelişmiştir (Kara, 2019: 29). İnternetin ilk uygulaması olan web 1.0 salt okunur interneti ifade etmektedir. Web 1.0' da yalnızca internette okuma yapmak ve bilgi aramak mümkündür ve kullanıcıların içeriğe katkısı bulunmamaktadır. Dolayısıyla, web 1.0 içinde internet kullanıcıları, yalnızca paylaştıkları içeriklerle yetinmektedir. Bu nedenle web 1.0, büyük ölçüde bir okuma ve araştırma mecrasıdır. Ancak ortaya çıktığı dönem için önemli bir teknoloji olan web 1.0, mevcut düzen ve gündelik yaşam içinde sorunsuz bir ağın başlangıcı olarak kabul edilmektedir (Laughey, 2010: 162-163).

Son on yıldaki teknolojik gelişmeler, 20 yıl önce bilim kurgu sayılabilecek şekillerde bilgiye aracılık edebilecek şaşırtıcı sayıda yeni cihazla sonuçlanmıştır. Bu teknolojiler yaygın olarak "yeni medya" olarak adlandırılmıştır. Bu adlandırma, 90'lı yılların ortalarında World Wide Web'in yaygın olarak benimsenmesinden beri kullanılan ve şu anda birbirine bağlı bilgisayar ağından çok daha geniş bir teknoloji yelpazesini kapsamaktadır (Yzer ve Southwell, 2008: 8). Çoklu ortam özelliğine sahip yeni medya ortamlar1; metin, durağan görüntü, hareketli görüntü, ses gibi özellikleri bünyesinde barındirmaktadır (Gackenbach, 2007: 277-278, Dilmen, 2007: 115).

Yeni medya ortamlarında, kullanıcılar içeriğe müdahale edebilmekte, içerik oluşturabilmekte, karş1lıklı etkileşim ve iş birliği içerisinde hareket edebilmektedir. Bu özellikler web 2.0 teknolojisi ile ortaya çıkmıştır. Ekonomik, sosyal ve ileri teknolojik eğilimleri bir araya getiren web 2.0, daha ileri düzeyde kullanıcı katılımını sağlayan bir teknolojiye dönüşmüştür. Getirdiği zengin kullanıcı deneyimi, kullanıcı katılımı, dinamik içerik, meta data, açıklık, özgürlük ve kolektif bilinç gibi yeniliklerle internet ortamında kullanıcı türevli içerik üretimi olanaklı hale gelmiştir (Güler, 2011: 53-54 ve Binark, 2012: 170).

Yeni medya ortamları ile birlikte ortaya çıkan "sosyal medya" sözcüğünün anlamını onu oluşturan iki terimden türetmek mümkündür. Basın genellikle pazarlama ve yayınların/ kanalların düşünce veya ayrıntıların etkileşimi ile ilgilidir. Topluluk ise bir takım veya grup içindeki kişilerin bağlantılarını ifade eder. Birlikte ele alındığında, sosyal medya, temel olarak, insanların belirli kişiler tarafından, belirli bir yöntem veya araç aracılığıyla üretildiği ve sürdürüldüğü iletişim/yayın sistemleri ile ilgilidir (SI, 2016: 1). Yeni medya ortamı içinde sosyal medya, çoklu ortama açıklık, interaktiflik, güncellenebilirlik gibi özellikleri ile yeni iletişim ortamları olarak önemli bir yere sahiptir. İnsanlar sosyal medya ortamlarında düşüncelerini paylaşabilmekte, bu düşünceler üzerinden tartışabilmekte, fotoğraflar, videolar paylaşabilmekte ya da alışveriş yapabilmektedirler (Vural ve Bat, 2010: 3349). Dolayısıyla sosyal medya ortamları, internet kullanıcılarının birbirleri ile çevrimiçi iletişim kurmalarına olanak veren, içerik paylaşımı ve kişisel yorumlar gibi etkinliklere dayalı sosyal ağ siteleridir. (Kirtiş ve Karahan, 2011: 262).

Sosyal medyanın sağladığı özellikler ve kolaylıklar doğrultusundan tüm dünyada giderek artan sayıda insan birbirleriyle bağlantı kurmak ve bilgi aramak gibi faaliyetler için sanal dünyada zaman harcamaya başlamıştır. Bu yaygın sosyal medya tüketimi, reklamcıların da sosyal medya ortamları için reklam üretmelerini beraberinde getirmiş ve sosyal medya mecraları reklamverenlerin tüketiciye ulaşmak için başvurdukları cazip 
ortamlar olmuştur. Günümüzde tüketiciler, içerik tüketmekten tartışmalara katılmaya, diğer tüketicilerle bilgi paylaşmaya ve diğer tüketicilerin faaliyetlerine katkıda bulunmaya kadar çeşitli etkinliklere katılmaktadırlar, bununla birlikte YouTube, MySpace, Facebook, Instagram, Twitter, Wikipedia gibi sosyal medya sitelerine olan yoğun ilgiyle, tüketiciler aktif olarak reklamcılık faaliyetlerine de katkıda bulunmakta ve tüketim kültürüne eklemlenmektedirler.

\section{Tüketim Kültürü ve Sosyal Medya}

Tüketim, ekonomik anlamda insanların ihtiyaçlarını gidermek için mal ve hizmetlere bedel ödeyerek sahip olmaları ya da onları kullanmalarıdır (Kadığlu, 2014: 15). Tüketim, ihtiyaçların hizmetindedir ve sosyo-kültürel ihtiyaçları da tatmin ederek yaşamı sürdürmeyi sağlamaktadır. Tüketimi, belirli ihtiyaçları tatmin etmek için bir ürünü ya da hizmeti arayıp bulmak, satın almak, kullanmak ya da yok etmek olarak tanımlamak mümkündür (Odabaşı, 2017: 5). Dolayısıyla tüketim, ihtiyaç, istek, arzu gibi taleplere ilişkin zamana ve mekâna da bağlı sosyal ve ekonomik birlikteliklere sahiptir. Söz konusu talepleri yerine getirmek için mal, hizmet, para ya da para yerine ikame edilen bir değer gerekmektedir.

Torlak, (2000: 17), tüketimi gerçek veya sahte olsun, bazı talepleri karşılamak için cesaretlendirilmiş maddi ve maddi olmayan değerler olarak tanımlamaktadır. Tüketim, tüketici satın alma kararları tarafından oluşturulmaktadır ve ekonomik malları kullanmak için davranışları birleştiren bir süreçtir. Tüketim sürecinin başlangıcında güdüler yer almaktadır. Bireyi, tüketim eylemine yönelten temel güdü ihtiyaçtır (Kadıoğlu, 2014: 1617). Tüketimin tanımındaki en önemli unsur da ihtiyacın tatminidir. Neo-klasik ekonomi kuramına göre ihtiyacın tatmini, mutluluğu beraberinde getirmektedir. Pazara bir isteği tatmin etmek için sürülen ürün ve hizmetler, bireysel yararı arttırmaktadır (Odabaşı, 2017: 10-14). Tüketim araçları, insanların mal ve hizmet edinmelerini sağlamakta ve ayrıca onları kontrol altında tutarak sömürmektedir. Basit bir ifadeyle tüketim, belirli ihtiyaçları karşılamak için bir mal veya hizmete sahip olmak, onu kullanmak veya elden çıkarmak anlamina gelmektedir.

Endüstriyel gelişmelerin yoğunlaşmasıyla seri üretim yöntemleri sonucu kitlesel üretime ulaşılan fordist dönemde tüketim, standart bir duruma gelmiştir. Bu dönemde montaja dayalı seri üretimin gerçekleşmesi için seri tüketimin gerçekleşmesi gerekmektedir (Slater, 1997: 191). Fordist dönem, sembolik olarak 1914'te başlamakla birlikte, asıl etkisini Henry Ford'un öncülügünü yaptığı seri üretim sistemlerinin gelişmeye başladığ 1930’lu y1llarda göstermeye başlamıştır. Seri üretim sistemleri, standart tüketim kalıpları oluşturmuş, bununla birlikte benzer mallardan oluşan toplu pazarın tüketicileri de oluşmaya başlamıştır (Harvey, 2010: 147-151 ve Murray, 1990: 47).

Fordist seri üretim ve toplu tüketim döneminde satın aldıkları metalarda seçim yapmaya başlayan meslek sahibi yeni tüketici grupları ortaya çıkmış, bu gruplar, tüketim kalıplarının değişmesini de etkilemişlerdir. Bu dönemde reklamlar aracılığıyla sabun tozu, otomobil, içecek, giyim eşyaları, mutfak gereçleri vb. pek çok üründe marka imajları 
önem kazanmıştır (Bocock, 1997: 31). Bu dönemde reklamcılık, kitle iletişim araçları ve eğlence endüstrisi, tüketim pazarının geliştirilmesi için etkin biçimde kullanılmıştır (Ewen, 1976: 33-34). Reklam metinleri, psikolojik tatmine, doyuma ve bilinçaltına seslenmiştir. Bireyin ürünle kurduğu ilişki sonucu yaşayacağı duyguların işlendiği metinlerde, ürünü kullanmamanın yaratacağı endişe ve reklamı yapılan ürünün tüketimiyle yaşanacak doyumun altı çizilmiştir (Leiss vd. 1990'dan aktaran Dağtaş, 2009: 27).

1960’lı yıllarda fordizmin ve Keynesçi politikaların kapitalizmin çelişkilerini denetim altında tutmasının mümkün olmadığı görülmeye başlanmış, kitlesel olarak üretilen mallara olan talepte farklılaşmalar, kullanılan teknolojik alt yapının yetersizliği ve artan krize bağlı olarak endüstri ilişkilerinin bozulması gibi nedenler fordist sistemi olumsuz etkilemiştir (Harvey, 2010: 164-165; Suğur, 1999: 139). Bu gelişmeler, "esnek üretim" ve "yalın örgütlenme" biçimlerinin ortaya çıktığı "post-fordist" dönemi beraberinde getirmiştir.

Post-fordist dönemde, pazarlar ve tüketim "yaşam biçim"lerine, "niş pazarlara", "pazar bölümlerine", "hedef tüketici" gruplarına ayrılmıştır. Post-fordizmin geniş anlamdaki önerisi, yeni yaşam biçimlerinin oluşturulması yönündedir. $\mathrm{Bu}$ dönemde hizmet sektörü önem kazanmış, ürün seçme olanağı artmıştır. Bununla birlikte ürün ömrü kısalmış, model değişimi hızlanmıştır. Tüketiciler, ürünlerin farklılaşması arzularını ve eğilimlerini açık biçimde göstermiş̧lerdir (Odabaşı, 2017: 18). Post-fordist dönemde tüketim ve reklam, bireysel kimliklerin belirlenmesinde önemli bir rol oynamıştır. Reklam metinlerinde reklamı yapılan ürün ya da ürünü kullananın kim olduğu önem kazanmıştır (Dağtaş, 2009: 31). Kimliklerin oluşumu ve tanınmasında yaşam biçimlerinin ön plana çıkması, reklam metinlerinde de yaşam biçimlerinin sunulmasını beraberinde getirmiştir (Davidson, 1992: 62).

Günümüzde ise tüketim ürünleri çeşit ve miktar olarak artmış, insan ilişkileri ve değerleri, daha fazla pazar koşullarına uygun olarak sunulur hale gelmiştir. Alışveriş bir boş zaman etkinliği olarak görülürken alışverişin farklı biçimleri ortaya çıkmıştır. Bununla birlikte boş zaman etkinlikleri ve spor tüketiminin görünümü artmıştır. Kredi kartları ve tüketici kredileri yaygınlaşmış, böylece iflas kavramında anlam değişikliği yaşanmıştır. Ürünlerin şekil, tasarım ve görünümlerine verilen önem ve reklamın günlük yaşamdaki etkisi artmıştır. Tüketim ürünleri ile ilgili olarak seçim yapmaya karşı koymak olanaksızlaşmış, kişisel ve kolektif koleksiyonlara duyulan ilgi artmıştır (Lury, 1996: 29)

Fordist ve post-fordist dönemde olduğu gibi günümüzde de reklamlar tüketim kültürünün lokomotifi olarak çalışmaktadır. Reklamlar, kapitalizmin ve tüketim kültürünün merkezindeki değerlerin devamlılığının sağlanmasına yardımcı olmakta, toplumsal ve kültürel değerlerin yeniden üretilmesini sağlamaktadır. Dolayısıyla kapitalist sistemin kendisini yeniden üretmesine yardımcı olan reklamlar aracılığıyla tüketime dayalı kimlikle ve yaşam biçimleri oluşmaya başlamıştır (Eryentü, 2017: 31).

Reklamlar, üretilen mal ve hizmetlerin tanitılmasında kullanılmakla birlikte, yeni değer kalıplarının toplumlara aktarılması, alışkanlıkların değiştirilmesi ve yeni alışkanlıklar edinilmesinde etkilidir (Kadığlu, 2014: 30). Bilgilendirme, ikna etme ve hatırlatma işlevi gören reklamlar, aynı zamanda tüketicilerin istek ve arzularına seslenerek 
onları ikna etmektedir (Ünal, 2014: 77-78). Aynı zamanda reklamlar, bireylerde anlık ve geçici kimlik yaratabilme gücüne de sahiptir (Bauman, 2006: 119). Bireyler, reklamlardan aldıkları mesajlar aracılığıyla kimliklerini inşa etmekte; giyim tarzından, dil kullanımına, boş zaman etkinliklerine, müzik tüketimine ve medya kullanımına kadar farklı materyal ve kültürel ögelere başvurmaktadırlar (Kadığ̆lu, 2014: 35).

Kitle iletişim araçlarından yayılan reklamlar, iletişim teknolojilerindeki gelişmelerle yayınlanma alanlarını genişletmiş, sosyal medyanın artan popülerliği ile reklamverenler sosyal ağlar üzerinden tüketicilerle iletişim kurma çabasına girmiştir. Bu çaba reklam tekniklerinin ve stratejilerinin de yeni medya ortamlarına göre yeniden şekillendirilmesini beraberinde getirmiştir. Böylece tüketim toplumunun ortaya çıktığı günden beri tüketimi yönlendiren ve manipüle eden reklamlar, daha etkin bir biçimde insan yaşamında var olmaya ve tüketim toplumunu yönlendirmeye ve manipüle etmeye devam etmektedir.

Reklamın kendisi büyük bir endüstridir. Bununla birlikte teknolojik gelişmelerle multimedya grupları ortaya çıkmış ve mega reklam grupları doğmuştur. Reklamcılığın yeni iletişim ortamlarına taşınmasıyla hem görünümü hem de özü değişmiştir. Reklamcılık artık etkileşimli ve multimedya ağ1 içinde yapılır hale gelmiştir. Bu durum üretici ve tüketici etkileşimine de yeni bir boyut getirmiştir (Mattelart, 1991:8; Trust ve Oliver, 1998: 95).

Yeni medya ortamları, firmalara yalnızca tüketici ile daha etkin bir iletişim kurmayı sağlamamakta, müşterilerin ürün hakkında neler düşündüğünü anlama ve ürünün yarattığı sosyal etkileşimi görme açısından da fayda sağlamaktadır. Sosyal medya, katılım ve içerik üretme özellikleriyle bireylere ürünün bir parçası olma olanağ 1 sunmaktadır (İşlek, 2012: 64). Sosyal medya ortamlarında tüketiciler, geleneksel ortamlara göre söz hakkına sahip olmaktadırlar. Dolayısıyla reklamverenler açısından sosyal medyadaki tüketici faaliyetlerini takip ederek tüketici davranışlarını belirlemek, hangi mecralarda nasıl bir hedef kitlenin olduğunu tespit etmek önemli hale gelmiştir. Öyle ki bilgi teknolojileri tüketicileri güçlendirmiş, pasif bilgi alıcısı olmaktan çıkararak aktif bilgi üreticisi haline getirmiştir. Tüketiciler daha önce reklamverenler tarafindan takip edilen faaliyetleri daha fazla yapar hale gelmişler dolayısıyla reklamlar da bu yönde evrilmiştir. Bu nedenle de reklamverenlerin sosyal medya kullanımından karşılıklı yarar sağlayabilmeleri için tüketicilerin davranışlarını daha iyi anlamaları gerekmektedir. Çevrimiçi alışveriş davranışlarının hızla arttığı günümüzde tüketiciler, içerik tüketmekte, tartışmalara katılmakta ve diğer tüketicilerin bilgilerine ve tüketim faaliyetlerine katkıda bulunmaktadırlar. Söz konusu aktif tüketici davranışı, reklamcılık faaliyetlerini değiştirirken tüketim etkinliğini de arttırmıştır. Bu nedenle sosyal medyanın sağladığı hız ve etkileşim tüketim kültürünün yayılmasını ve artmasını da besler duruma gelmiştir.

Günümüzde tüketim, ürün ve hizmetler dolayımıyla bireylerin ihtiyaçlarını gidermenin ötesinde bir "gösterge sistemi”ne dönüşmüştür. Tüketim hem bir ideoloji hem de bir dil olarak ele alınıp incelenmelidir. Tüketim toplumunda tüketim öğrenilmektedir. Söz konusu bu toplum, yeni üretim güçlerinin ortaya çıkması ve verimlilik taşıyan ekonomik bir sistemin tekelci yapılanmasıyla orantılı yeni ve özgül bir toplumsallaşma biçimidir. Tüketim toplumundaki alışverişin önemli bir bölümü sosyal medya aracılığıyla 
yapılmaktadır. (Baudrillard, 2000: 90). Başka bir deyişle günümüzde tüketim artık ihtiyaçların ötesine geçmiştir. Bireyler tükettikleri ürünlerle anılır duruma gelmişlerdir. $\mathrm{Bu}$ nedenle tüketim sosyal bir statü, prestij ve kimlik sağlamak adına yapılır duruma gelmiş, "tüketmiş olmak için tüketme" anlayışı hâkim olmuştur. Baudrillar'a paralel olarak Belk (1995:72) de kimlik inşası ve nesnelerin tüketimi arasında bir ilişki olduğunu belirtmektedir. Bireyin tutkularını, yeteneklerini ve egosunu tatmin eden nesneler; kimliğin açıklayıcısı olarak işlev görmekte ve kimliğin algılanmasına, sürekliliğine ve kimliğe dair ölümsüzlük hissinin oluşmasına yardımcı olmaktadır.

Kapitalist toplumlarda tüketim alanı, insanın var oluşunun bir bölümdür. Tüketim ve boş zaman etkinlikleri de sermayenin denetimindedir. Kapitalizm, toplumun tamamını kendi çıkarlarını gerçekleştirme yönünde organize etmektedir. Kapitalist toplumun aydınları, tüketim olgusunun bilimsel bir görünüş kazanmasında ve toplumun tüketim yönünde şartlandırılmasında önemli bir görev üstenmektedir. Kapitalist toplumsal yapının en altında olan bireyler, birbirinden yalıtılmıştır. Böylece birer araca dönüştürülen bireyler hem üretim hem de tüketim sürecinde sistemin kendisini yeniden üretmesine hizmet etmektedir (Yaylagül, 2008: 92).

Kapitalist sistemin sürekliliğinin sağlanması, üretimin; üretimin sürekliliği de tüketimin sürekliliğini gerektirmektedir. Temelde bireylerin temel geçim ihtiyaçlarının karşılanması olan tüketim, kapitalist sistemin bir aracı olarak bireylerin toplum içindeki yerlerini belirleyen bir göstergeye dönüşmüştür. Daha önce de belirtildiği gibi bireyin, toplumsal konumu tükettikleri ile ölçülmektedir. Bireyin toplum içindeki konumunun tüketim ile sağlanacağı algısı ise reklamlarla yaratılmaktadır (Çetinkaya, 1992: 85)

Kapitalist toplumda her şey tüketim boyutu ile anlam kazanmaktadır. Kültür endüstrisinde, kültürün kendisi de bir endüstri haline gelmiştir. Adorno ve Horkheimer'e göre, kültür endüstrisi tekellerin egemenliği altındaki kitle kültürünün özdeşliğine dayanmaktadır. Birbirine karışmış olan kültür endüstrisi ve reklamlar, insanların yönlendirilmesi işlevini görmektedir. Kültür endüstrisinde reklamlar, tüketicileri bu endüstrinin ürünlerini almaya zorlamaktadır (Bottomore, 2016: 52). Herbert Marcuse (1990: 10-11) de kültür endüstrisinin yanlış bilinç geliştirdiğini, üretici aygıt ve ürettiği mal ve hizmetlerin bir bütün olarak toplumsal dizgeyi sattığını/dayattığını ifade etmektedir. Bu bağlamda reklamlar da bir ürünün özelliklerini tanıtmaktan çok bir yaşam biçimi olarak tüketimi özendirmektedir. Reklamlar, yalnızlık, rahatsızlık, yorgunluk gibi hoşnutsuzluklara tüketimi bir çare olarak sunmaktadır (Lasch, 2006:125).

Günümüz dünyası, bir tüketim toplumuna dönüşmüştür ve bu dünyada tüketim malları tüketim kalıpları kimliklerin toplumsal ve kültürel oluşumunda önemli bir yere sahiptir. Günümüzde kimlikler, satın alınabilir, kısa süreli, kolaylıkla sökülebilir ve tamamen değiştirilebilir bir niteliğe sahiptir ve bireyler, toplumsal kimliklerini sosyal medya üzerinden şekillendirmeye başlamışlardır (Özdemir, 2015: 113). Tüketim nesnelerinin bireylerin kimliklerinin bir parçası haline geldiği günümüzde, bireyler tükettikleri ile değerlendirilmeye başlamıştır ve topluma yayılan "insan tükettiği ürün bazında değer kazanır” algısı günümüzde büyük ölçüde özellikle sosyal medya tarafından yayılmaktadır. Dolayısıyla sosyal medya, tüketim kültürünün ortaya çıktığı ilk günden 
beri medyanın üstlendiği sistemin devamlılığını sağlama ve tüketim kültürünü yayma işlevini sürdürmeye devam etmektedir. Dolayısıyla, tüketim kültürünün lokomotifi olan reklamcılık sektörü için de sosyal medya, sistemin sürekliliğini sağlamada önemli bir aracı olarak karşımıza çıkmaktadır. Günümüzde geleneksel kitle iletişim araçlarının sınırlarını da ortadan kaldırarak, dünyayı küresel bir kente dönüştüren sosyal medya, reklamverenler için de önemli bir mecra haline gelmiş, tüketim kültürünün yayan, genişleten ve yeniden üreten bir mecra olmuştur.

\section{Black Friday (Kara Cuma) Nedir?}

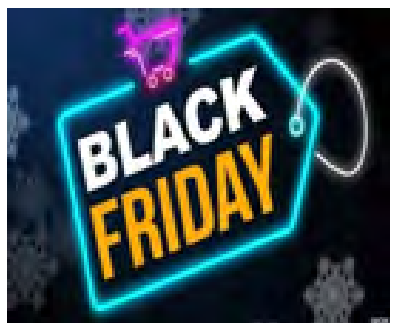

Black Friday, ABD'de Şükran Günü'nden sonraki ilk cuma gününü ifade etmektedir ve 1932 'den bu yana Noel alışveriş sezonunun başlangıcı kabul edilmektedir. $\mathrm{Bu}$ dönemde mağazalar günün erken saatlerinde çalışmaya başlamakta ve geç saatlerde kapanmaktadır. Ve bu günde mağazalar her zamankinden daha fazla oranda indirimli satış yapmaktadırlar. ${ }^{1}$

Başlangıçta Noel alışveriş günü olan gün, 1961 yılında "Kara Cuma" olarak anılmaya başlanmıştır. ABD'de Black Friday gününde indirim kampanyaları, alışverişe olan talebi arttırmış, bu talep artışı Şükran Günü'nden sonraki Cuma günlerinin yoğun bir biçimde geçmesine neden olmaya başlamıştır. 1961 yılında yoğunluk yüzünden araçlar yerinden kıpırdayamaz hale gelmiş ve insanlar birbirlerini ezmiştir. Bu nedenle bugüne Black Friday (Kara Cuma) denmeye başlanmıştır.

Son yıllarda ise tüketim kültürünün artışıyla "kara" sözcügü anlam iyileşmesine uğrayarak "indirim ve alışveriş" günü olarak anılmaya başlamıştır. Türkiye'de de 29 Kasım'da gerçekleşen gün hem markaların hem de tüketicilerin beklediği bir gün haline gelmiştir. Markalar bu günlerde özel indirimler, kampanyalar yapmakta; kampanya tanıtımları günler öncesinden yapılmakta, 29 Kasım günü hem mağazalarda hem de internet ortamlarında yoğun bir alışveriş trafiği yaşanmaktadır.

\section{Yöntem}

$\mathrm{Bu}$ çalışmada sosyal medya ortamlarının tüketim kültürünün devamlılığını nasıl sağladığını görmek adına örnek olay incelemesi yapılmıştır. Örnek olay incelemesi, literatürde durum çalışması olarak da adlandırılmaktadır. Bir birey, bir kurum, bir ortam vb. üzerine örnek olay analizi yapmak mümkündür. Örnek olay analizinde ele alınan duruma ilişkin etkenler bütüncül bir yaklaşımla araştırılmaktadır. Birden fazla veri toplama tekniğinin kullanılabildiği örnek olay analizinde betimleme, örnekleme, temaları ve örüntüleri ortaya çıkarma ve karşılaştırmalı analiz gibi veri analizi yöntemleri kullanılmaktadır ve durumların tek başına ve/veya karşılaştırmalı olarak tanımlanması ve yorumlanması yapılmaktadır (Yı1dırım ve Şimşek, 1999: 83-85).

1 Black Friday nedir, ne anlama geliyor? https://www.cnnturk.com/teknoloji/black-friday-nedir-ne-anlamageliyor, Erişim Tarihi: 01.02.2020. 
Örnek olay analizi, güncel bir olguyu kendi gerçek yaşam çerçevesi içinde inceleyen ampirik bir araştırma yöntemidir (Yin, 1994). Örnek olay analizi, bir süreci, kişiyi, hayvanı, evi, organizasyonu, grubu, endüstriyi, kültürü ya da bir milleti tanımlamaya, anlamaya, tahmin etmeye ya da kontrol etmeye odaklanmaktadır (Woodside ve Wilson, 2003: 493). Örnek olay analizinde amaç, bir olayı ayrıntılarıyla inceleyerek ortaya koymaktır, bu nedenle genelden ziyade belirli bir durumla ilgilenilmektedir. Örnek olay analizi, bütüncül bir bakış açısı içinde gerçekleşmekte ve belli bir zaman periyodunda gelişen olayları incelemektedir. Örnek olay analizinde araştırmacı, olguyu, olgular arasındaki ilişkileri derinlemesine anlamaya ve tecrübe edilenleri anlamlandırmaya çalışmaktadır (Baş ve Akturan, 2013: 181-183). Bu bağlamda çalışmada Trendyol'un Black Friday günlerinde sosyal medya ortamlarında yayımladığı reklamlar üzerinden bütüncül bir örnek olay analizi yapılmıştır.

Kampanya süresince "Trendyol Efsane Günler” genel adı altında altı tane reklam yayınlanmıştır. Bunlar:

-Trendyol Efsane Günler Enis Arıkan'ın Gözünü Alamadığı Fırsatlar

-Trendyol Efsane Günler Aybuke Pusat ve Furkan Andıç’ın Gözünü Alamadığı Firsatlar

-Trendyol Efsane Günler Muslera'nın Gözünü Alamadığı Fırsatlar

-Trendyol Efsane Günler Burcu Esmersoy’un Gözünü Alamadığı Firsatlar

-Trendyol Efsane Günler Gülse Birsel'in Gözünü Alamadığı Fırsatlar

-Trendyol Efsane Günler Vedat Milor’un Gözünü Alamadığı Fırsatlar adları ile yayımlanmıştır.

Çalışmada öncelikle Trendyol'un sosyal medya mecralarındaki hesapları ile ilgili bir çerçeve çizilmiş. Sonrasında ise her bir reklamın tasarım dili hakkında bilgi verilerek sosyal medya mecralarındaki görüntülenme oranları, aldıkları beğeni ve yorumlara ilişkin karşılaştırılmalı bir analiz yapılmıştır. Reklamlar sosyal medya ve tüketim kültürü bağlamında değerlendirilmiştir.

\section{Bulgular ve Yorumlar}

\section{Sosyal Mecralarda Trendyol Mobil Teknoloji Şirketi}

Haziran 2009'da 300 bin dolar sermaye ile kurulan e-ticaret şirketi olan Trendyol, günümüz itibariyle 16 milyon üyeye sahiptir. Şirketin Instagram, Youtube, Twitter, Facebook hesapları bulunmaktadır.

Twitter'da Trendyol

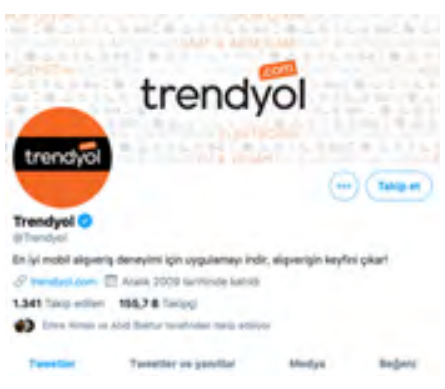


Trendyol, sosyal medya mecralarındaki ilk hesabını Twitter'da açmıştır. Aralık 2009'da Twitter'a katılan şirketin 155 binin üstünde takipçisi bulunmaktadır. Katıldığ günden bugüne şirket, 78 binin üzerinden tweet atmıştır. Bu tweetlerden 7268 tanesi fotoğraf ve videodur. Toplamda 3584 beğeni alan şirketin 1341 hesabı takip etmektedir. Şirketin takip ettiği hesaplar genellikle ünlü kişiler, sayfalar ve markalardır.

Şirket, Twitter'da her gün aktif paylaşım yapmamakla birlikte genellikle özel günler (30 Ağustos, 29 Ekim, $10 \mathrm{Kasım,} 24 \mathrm{Kasım}$ vb.) ve kampanya süreçlerinde paylaşım yapmiştır.

\section{Facebook'ta Trendyol}

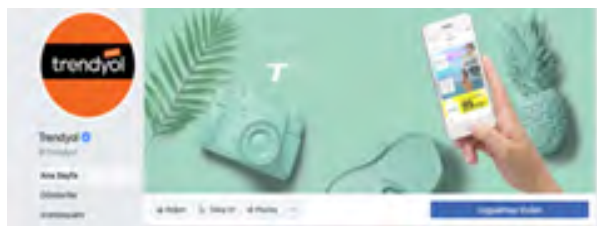

18 Mart 2010 tarihinde Facebook'a katılan şirketin 2.412.161 takipçisi bulunmaktadır. Şirketin Facebook sayfası toplamda 2.412.144 beğeni almıştır.

Trendyol, Facebook ana sayfasında, Uygulamayı Kullan butonuyla takipçilerini direk App Store'deki veya Google Play Store'deki Trendyol uygulamasına yönlendirmektedir. Sayfada düzenli aralıklarla paylaşım yapılmamaktadır. 1259 kişi tarafından tavsiye edilen hesap, 36 bin 818 kişinin değerlendirmesi ile 5 üzerinden 3.7 almıştır.

\section{Youtube'de Trendyol}

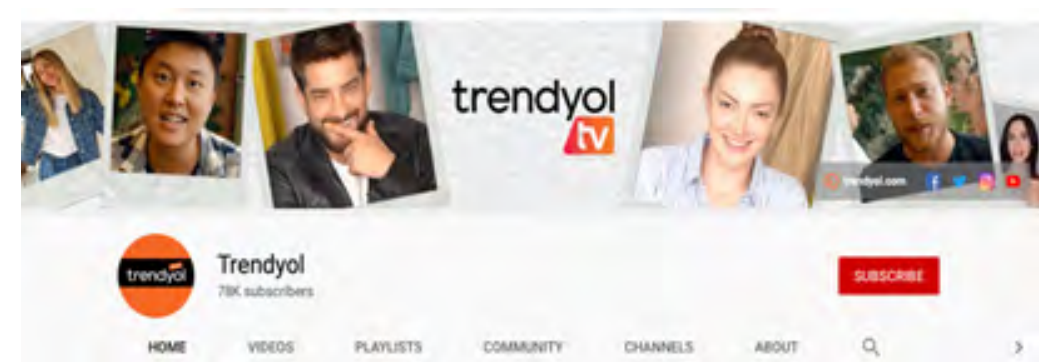

Trendyol, 29 Temmuz 2010 tarihinde Youtube'a katılmıştır. Kanalın 78 bin abonesi bulunmaktadır. Kanalda 349 paylaşım yapılmıştır. Toplam görüntülenme sayıs1 132,880,551'dir. Paylaşımların belirli bir periyodu olmamakla birlikte kampanya zamanlarında paylaşım sayısının arttığı görülmektedir. Şirket yalnızca kendi ürettiği içerikleri değil, Youtuberlar tarafından çekilen ve Trendyol'dan alınan ürünlerin tanıtıldı̆̆ 1 videoları da kanalında paylaşmaktadır. 


\section{Instagram'da Trendyol}

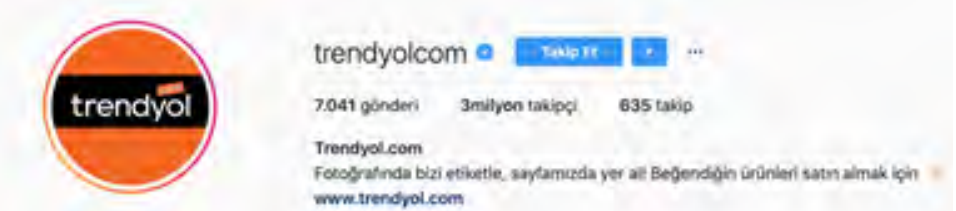

Trendyol.com kullanıcı adıyla, 21 Eylül 2012 tarihinde Instagram'a katılan şirketin 3 milyon takipçisi bulunmaktadır. Şirket, içinde Türk ve Yabancı ünlülerin, sayfaların ve markaların olduğu toplan 635 hesabı takip etmektedir. Şirketin 8 Şubat 2020 itibariyle 7041 gönderisi bulunmaktadır. Günlük paylaşım sayısına bakıldığında kampanya zamanları hariç, günde 4 ya da 5 paylaşım yapıldığı görülmektedir.

Insta story bölümünü de aktif olarak kullanan şirket hemen hemen her gün hikâye paylaşımında bulunmaktadır. Trendyol, Instagram hesabındaki paylaşımlarında link vererek takipçilerini Instagram içerisindeki mağaza bölümüne yönlendirmekte, mağazada beğenilen ürünlerini satın almak isteyen takipçilerini Trendyol sitesine veya uygulamasına aktarmaktadır.

Trendyol'un sosyal medya hesaplarına bakıldığında en çok takipçisinin 3 milyon kişi ile Instagramda olduğu görülmektedir. Bu rakamı 1 milyonun üzerindeki takipçi sayısı ile Facebook takip etmektedir. 155 bin takipçi sayısı ile Twitter hesabı üçüncü sırada yer alırken, Youtube hesabı 78 bin takipçi ile dördüncü sıradadır. Şirketin en çok paylaşımı ise Twitter'da (78.499) yaptığı görülmektedir. Instagram'da 7041 paylaşım yaptığı görülürken Youtube'de 349 paylaşım yapmıştır. Facebook’taki paylaşım sayısı ise hesapta toplam veri olarak verilmemektedir.

\section{Trendyol Efsane Günler Reklam Kampanyalart}

\section{Trendyol Efsane Günler-Enis Arıkan'ın Gözünü Alamadı̆̆ı Fırsatlar Reklamı}

Reklam, bir hayvan hastanesinin bekleme salonunda geçmektedir. Bu salonda pet shop bölümünün olduğu ve hayvanlar için gerekli malzemelerin satıldığı bir bölüm bulunmaktadır. Ana karakteri oynayan Enis Arıkan, Trendyol alışveriş uygulamasından önce kişisel bir eşya olarak ayakkabı bakmaktadır. Pet shop görevlisi kucağında köpekle Enis Arıkan'ın yanına gelerek köpeğinin onu çok sevdiğini anlatmaya çalışır. Enis Arıkan ilgileniyormuş gibi gözükse de gözünü telefonundaki Trendyol indirimlerinden alamamaktadır. Trendyol uygulamasındaki alışveriş ve indirimler çok daha fazla dikkatini çekmektedir. Veterinerin pet shop bölümünde çalışan satış görevlisinin reklamın sonunda arka planda bir şeyler sattığı görülmektedir.

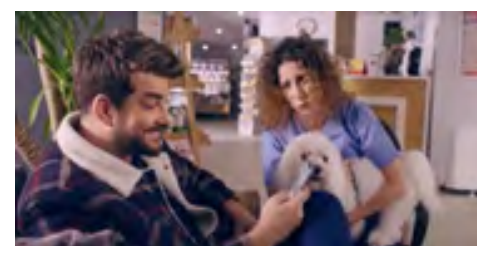


Enis Arıkan gözünü Trendyol'daki indirimlerden alamadığı için köpeğin başı yerine kadının başını sevmektedir. Böylece Trenadyol'daki fırsatların etraftaki her şeyden çok daha cazip olduğu fikri uyandırılmaktadır. Burada satış görevlisi, gerçek hayattaki pazarlamay1, telefon ise Trendyol'u imgelemektedir. Reklamın sonunda ise Enis Arıkan bir pet shopta olmasına rağmen telefonundan evcil hayvan aksesuarı bakmaktadır. Böylece internet üzerinden alışverişin daha cazip olduğu algısı yaratılmaktadır. Reklama hedef kitle açısından bakılacak olursa hayvan besleyen insanların hedef alındığ 1 görülmekle birlikte herhangi bir mağazadan alışveriş yapmak yerine Trendyol'dan alışveriş yapanların çok daha avantajlı olacağına vurgu yapılmaktadır.

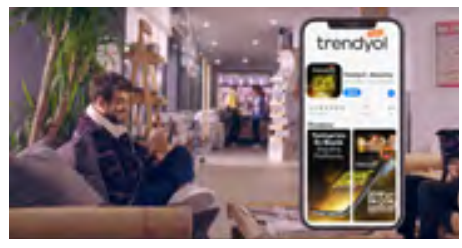

Reklamın sonunda “Trendyol Efsane Günler için 25 Kasım’1 bekle” sözleri duyulurken Trendyol mobil uygulamasının görüntüsü gelmektedir. Böylece tüketicilere mobil uygulamayı indirmeleri halinde çok daha kolay alışveriş yapabilecekleri mesajı verilmektedir.

Tablo 1. Enis Akıran'ın Gözünü Alamadığı Fırsatlar Reklamı Sosyal Medya Verileri

\begin{tabular}{|c|c|c|c|c|c|c|c|}
\hline & 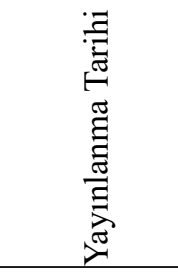 & 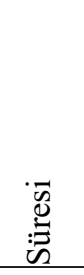 & 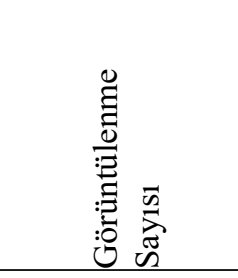 & 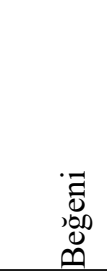 & $\begin{array}{l}\stackrel{\mathscr{y}}{=} \\
\stackrel{n}{0}\end{array}$ & $\underset{\partial}{\Xi}$ & 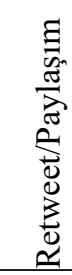 \\
\hline YOUTUBE & 21.11.2019 & $38 \mathrm{~s}$. & 1 milyon300bin & 45 & 130 & - & - \\
\hline INSTAGRAM & 21.11.2019 & $38 \mathrm{~s}$. & 150bin 821 & 4312 & - & 39 & - \\
\hline TWITTER & 21.11 .2019 & $38 \mathrm{~s}$. & 8 bin 360 & 14 & - & 43 & 3 \\
\hline FACEBOOK & 21.11 .2019 & $38 \mathrm{~s}$. & 10 bin & 56 & 3 & 19 & 5 \\
\hline
\end{tabular}

Reklamın şirketin sosyal medya hesaplarındaki görüntülenme rakamlarına bakıldığında en çok Youtube'da görüntülendiği görülmektedir. En fazla beğeniyi ise Instagram'da almıştır. Reklam toplamda 4427 beğeni alırken, 133 kişi tarafından ise beğenilmemiştir. Reklam toplamda yaklaşık 1.5 milyon izlenme rakamına ulaşmıştır. Bu rakamlar dikkate alındığında sosyal medya hesaplarından çok sayıda kişiye ulaşmanın mümkün olduğu görülmektedir. Aynı zamanda sosyal medya ortamlarının sağladığı geri bildirim döngüsü de şirketin reklamın tüketici üzerindeki etkisini ölçmesi açısından 
önemlidir. Alınan geri bildirimler doğrultusunda yeni stratejiler geliştirerek ya da olumlu tepki alınması halinde var olanı sürdürerek tüketicileri alışverişe yönlendirmek mümkündür.

\section{Trendyol Efsane Günler-Aybüke Pusat ve Furkan Andıç’ın Gözünü Alamadığı Fursatlar}

Reklam, Trendyol reklam filmi için yapılan ön hazırlık aşamasını konu almaktadır. Reklama "Yılın En Büyük Kampanyası" cümlesi ile giriş yapılır. Ajansta toplantı masasında bulunan kişilerin, turuncu renk ağırlıklı giysileri Trendyol markasını çağrıştırmaktadır. Ayrıca ilk sahnede "Trendyol" internet sitesinin bilgisayarda açık halde bulunması dikkat çekmektedir.

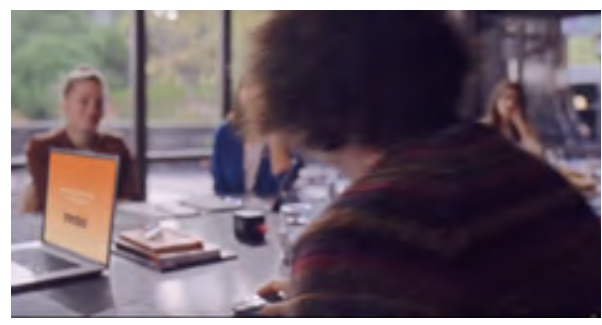

Burada “Trendyol ve Yılın En Büyük Kampanyası" arasında bir özdeşim kurulmaya çalışarak tüketicinin zihninde yer edinemenin hedeflendiğini söylemek mümkündür.
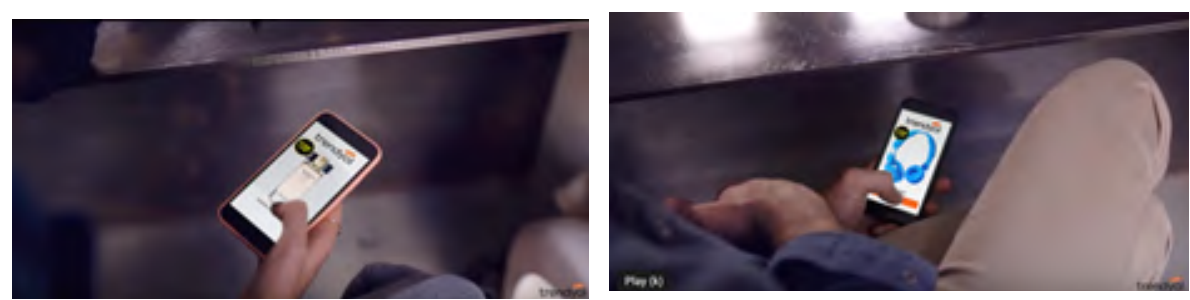

Ana karakterlerden biri olan Aybüke Pusat'ın, telefonundan kadın parfümü baktığı, diğer bir ana karakter olan Furkan Andıç'ın da telefonundan bir kulaklığa baktığ 1 görülmektedir. Her iki karakter de baktığg ürünleri sepete eklemektedir. Burada Trendyol'daki ürün çeşitliliğine dikkat çekilerek ürün yelpazesinin geniş olduğu vurgulamaktadır. Bir extreme spor olan bungee jumpingin isminin değiştirilerek, indirim kelimesiyle harmanlandığı ve reklam kampanyasına "Bungeendirim" adı verildiği görülmektedir.

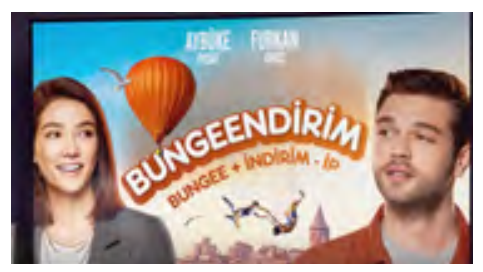

Senaryodan bahseden reklam filminin yönetmeni, bir Kapadokya balonundan Trendyol brandasına atlayacaklarını söylemekte ve Aybüke ve Furkan'ın düşüşüyle birlikte 
fiyatların da düşüşe geçeceğini belirtmektedir. Dolayısıyla Trendyol indirimleri extreme bir olaymış gibi yansıtılarak, extreme bir spora benzetilmektedir. Böylece tüketicide fiyatlarda oldukça fazla indirim olacağı algısı oluşturulmaktadır. Reklamın sonunda Enis Arıkanlı reklamda olduğu gibi Trendyol mobil uygulaması ekrana gelmektedir. Böylece tüketiciler mobil uygulamayı indirmeye yönlendirilmektedir.

Tablo 2. Aybüke Pusat ve Furkan Andıç’ın Gözünü Alamadığı Fırsatlar Reklamı Sosyal Medya Verileri

\begin{tabular}{|c|c|c|c|c|c|c|c|}
\hline & 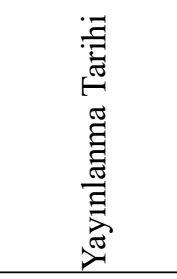 & $\begin{array}{l}\vec{w} \\
\vdots \\
\vdots \bar{n}\end{array}$ & 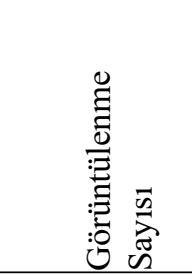 & $\begin{array}{l}\vec{D} \\
0 \\
0 \\
0 \\
0\end{array}$ & 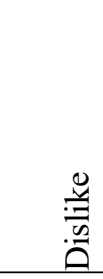 & $\underset{\partial}{\Xi}$ & 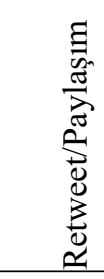 \\
\hline YOUTUBE & 21.11.2019 & $45 \mathrm{~s}$. & 106 bin 862 & 225 & 54 & Kapalı & - \\
\hline INSTAGRAM & 21.11 .2019 & $45 \mathrm{~s}$ & 18658 & 4312 & - & 401 & - \\
\hline TWITTER & 25.11 .2019 & $45 \mathrm{~s}$. & 7 bin 542 & 274 & - & 27 & 85 \\
\hline
\end{tabular}

Reklam, Trendyol'ın dört sosyal medya hesaplarında yayımlanmış, en çok Instagram'da görüntülenmiştir. Youtube'daki görüntülenme oranı ise 106 bin ile ikinci sırada yer almaktadır. Reklamın en çok beğeniyi de yine Instagram'da aldı̆̆ 1 görülmektedir. Toplamda 364 binin üzerinde görüntülenme rakamına ulaşan reklam, 19 binin üzerinde beğeni almıştır. Aldığı toplam beğeni sayısı dikkate alındığında reklamın hedefine ulaştığını söylemek mümkündür.

\section{Trendyol Efsane Günler-Muslera'nın Gözünü Alamadı̆̆ı Fırsatlar}

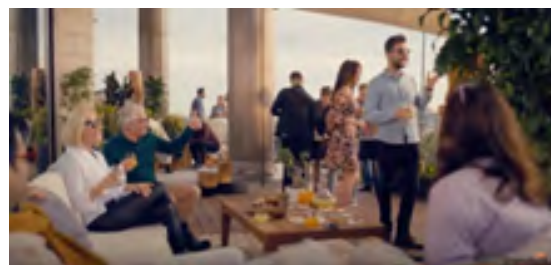

Reklam bir teras katında toplanan ve orta-üst sınıfın katıldığı bir parti ortamında geçmektedir. Reklamın ana karakteri Galatasaray kalecisi Muslera'dır. Muslera da ortaüst gelir grubuna ait bir bireydir. Langırt oynayan Muslera ve arkadaşları heyecanla maç yapmaktadır ve Muslera langırt oyununda gerçek hayattaki mesleği olan kaleci konumundadır. Topun ağır bir şekilde kaleye ilerlemesi sonucu Muslera hayatta en iyi yaptığı şeylerden biri olan kalecilik adına pek bir çaba harcamayarak gol yemektedir. Çünkü Muslera o sırada telefonundan Trendyol indirimlerini takip etmektedir. Muslera gol yemesine rağmen ekranda gördüğü indirimden dolayı sevinmektedir. 


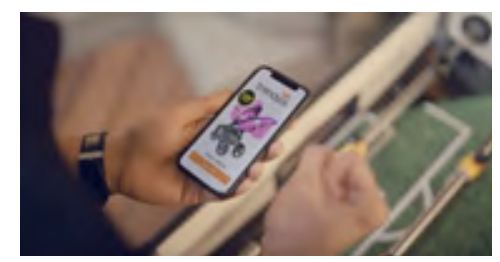

Langırt oyunundaki oyuncuların ve topun rengi turuncu ağırlıklıdır bu da Trendyol'un renklerini temsil etmektedir. Burada hedef kitleye yönelik bir tespit yapılacak olursa Muslera gibi orta-üst gelir grubuna ait bireylerin de ihtiyaçlarını giderecek ve onlara cazip gelecek kadar önemli indirimlerin olduğu algısı yaratılmıştır. Ayrıca baktığ1 ürün olan bebek arabasından yola çıkılarak çocuklu aileler ve çocuk bekleyen ailelerin de hedef kitle olduğu söylenebilir. Orta-üst sınıftan bireylerin de Trendyol'dan alışveriş yaptığının gösterilmesi, tüketim kültürünün bir yönü olan kimlik yaratımının da bir göstergesidir. Böylece tüketiciye "Trendyol'dan alışveriş yapmak sizi prestijli yapar" mesaj1 verilmektedir.

Tablo 3. Muslera'nın Gözünü Alamadığı Fırsatlar Reklamı Sosyal Medya Verileri

\begin{tabular}{|c|c|c|c|c|c|c|c|}
\hline & 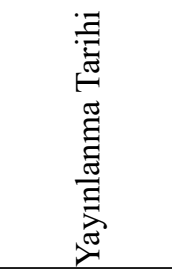 & 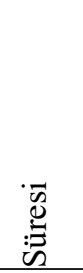 & 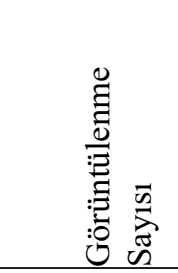 & 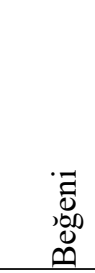 & $\begin{array}{l}\ddot{0} \\
: \vec{y} \\
\ddot{\theta}\end{array}$ & $\underset{\Xi}{\Xi}$ & 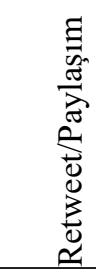 \\
\hline YOUTUBE & 21.11.2019 & $25 \mathrm{~s}$. & 127 bin & 147 & 45 & Kapal1 & - \\
\hline INSTAGRAM & 21.11.2019 & $25 \mathrm{~s}$. & 142 bin 208 & $\begin{array}{l}9 \text { bin } \\
740\end{array}$ & - & 166 & - \\
\hline TWITTER & 25.11.2019 & $25 \mathrm{~s}$. & 4 bin 895 & 22 & - & 25 & 3 \\
\hline FACEBOOK & 21.11 .2019 & $25 \mathrm{~s}$. & 14 bin 200 & 50 & 3 & 13 & - \\
\hline
\end{tabular}

Trendyol Efsane Günler kampanyasının Muslera'nın yer aldığı reklamı diğer iki reklamda olduğu gibi en çok görüntülenme rakamına Instagram'da ulaşmıştır. Youtube ise yine ikinci sırada yer almaktadır. Toplamda 288 binin üzerinde görüntülenme rakamına ulaşan reklam, yaklaşık 10 bin beğeni almıştır. Görüntülenme rakamı ile doğru orantılı olarak beğeninin en çok olduğu mecranın Instagram olduğu görülmektedir. Bu durum Instagram'ın son dönemde diğer sosyal medya mecralarına göre artan popülerliğini de göstermektedir. Daha çok görsel imgelerin (Fotoğraf, video vb.) paylaşıldığı bu mecra insanların son dönemlerde daha çok vakit geçirdikleri bir mecra olmuştur. Özellikle dijital yerliler, bu mecrada daha çok vakit geçirmektedirler. Trendyol'un da bu mecra aracılığıyla genç ve orta yaş tüketici grubuna ulaşması mümkündür.

\section{Trendyol Efsane Günler-Burcu Esmersoy'un Gözünü Alamadı̆̆ Fırsatlar}

Reklam mekânı, orta sınıf insanların gidebileceği bir restauranttır. Ana karakter 
olan Burcu Esmersoy, elindeki telefona dalmış bir şekilde tabağındaki çorbayı içmektedir. Fakat kaşık kullanması gerekirken çatal kullanmaktadır ve bunun farkında değildir. Dolayısıyla arkadaşlarının alay konusu olmuştur.

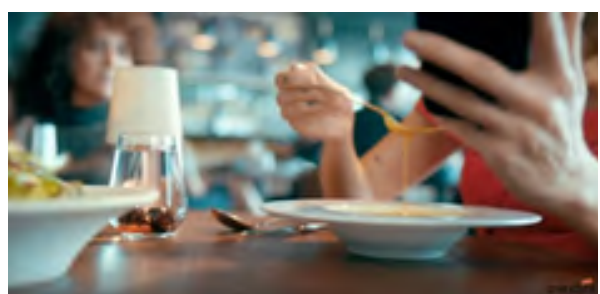

Arkadaşları, Burcu Esmersoy'a "Burcu sen ne yapıyorsun?" sorusunu yöneltmişlerdir. Yöneltilen bu soruyla aslında çatalla çorba içmenin absürtlügüne vurgu yapmak isterlerken, Burcu Esmersoy bu soruya gayet doğal bir ifadeyle iyi olduğu cevabını vermektedir. Arkadaşları ikinci kez aynı soruyu sorduklarında "Trendyol'da indirim var" cevabını duymaktadırlar. Burcu Esmersoy'u bu derece gerçek hayattan uzaklaştıran şey, aslında telefonundan baktığı Trendyol indirimleridir. Bunu duyan arkadaşları hızlı bir şekilde telefonlarına sarılmaktadırlar.

Burcu Esmersoy'un Trendyol sitesinden baktığı ürün, bir kadın elbisesidir. Trendyol'da modaya yönelik ürünlerin bulunduğu mesajı verilmiştir. Hedef kitlenin ise ş1k giyinmeyi seven kadınlar olduğunu söylemek mümkündür.

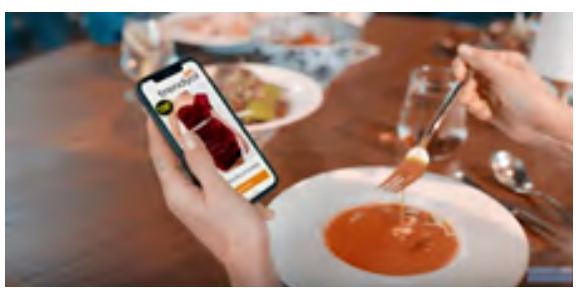

Reklamın sonunda Burcu Esmersoy'un arkadaşları da Trendyol sitesine girerek, birbirlerine beğendikleri ürünleri göstermektedirler. Burcu Esmersoy arkadaşının beğenip gösterdiği ürünü aldığını dile getirerek önceden Trendyol'dan ürün aldığını söylemektedir. İnternet ortamında yapılan alışverişlere karşı sergilenen güvensizliği yıkarak Trendyol'dan ürün aldığını belirtmektedir.

Diğer reklamlarda olduğu gibi bu reklamın sonunda da Trendyol mobil uygulaması ekrana gelmektedir. Günümüzde artık hemen her kesimden bireyin ihtiyacı ya da alım gücü olsun olmasın akıllı telefonu bulunmaktadır. Bu da tüketim kültürünün bir sonucudur. İnternet teknolojilerinin gelişmesiyle mobil uygulamalarla alışveriş siteleri de cep telefonlarına girmiştir. Kampanya reklamlarının sonunda mobil uygulamanın ekrana getirilmesi artı "mağaza cebinizde" mesajı vermektedir. Böylece mağazaya gitmeden hatta bir bilgisayara bile gerek olmadan alışveriş yapmanın mümkün olduğu vurgusu yapılmaktadır. İnsanların hayatlarını kolaylaştıracak uygulamalara daha çok yöneldiği günümüzde alışverişin kolaylaştırılması, tüketimi de hızlandırmakta ve artırmaktadır. 
Tablo 4. Burcu Esmersoy’un Gözünü Alamadığı Fırsatlar Reklamı Sosyal Medya Verileri

\begin{tabular}{|c|c|c|c|c|c|c|c|}
\hline & 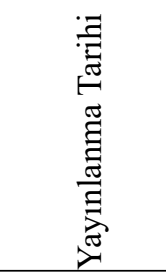 & $\stackrel{\bar{s}}{:}$ & 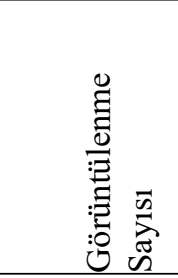 & 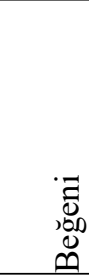 & 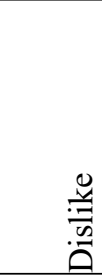 & $\underset{\Xi}{\Xi}$ & 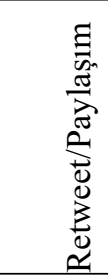 \\
\hline YOUTUBE & 21.11 .2019 & $30 \mathrm{~s}$. & 209 bin & 30 & 93 & Kapal1 & - \\
\hline INSTAGRAM & 21.11 .2019 & $30 \mathrm{~s} .$. & 142 bin 588 & $\begin{array}{l}4 \text { bin } \\
491\end{array}$ & - & 98 & - \\
\hline TWITTER & 25.11 .2019 & $30 \mathrm{~s}$. & 2 bin 418 & 6 & - & 28 & 1 \\
\hline FACEBOOK & 21.11 .2019 & $30 \mathrm{~s} .$. & 11 bin & 74 & 4 & 9 & 6 \\
\hline
\end{tabular}

Kampanyanın Burcu Esmersoy'un yer aldığı reklamının sosyal medya hesaplarındaki verilerine bakıldığında en çok görüntülenmenin Youtube da olduğu görülmektedir. Instagram ise bu reklam için ikinci sırada yer almaktadır. Reklam toplamda 365 bin görüntülenme rakamına ulaşmıştır. En çok görüntülenmenin Youtube'da olmasına karşın en çok beğeninin Instagram' da olduğu görülmektedir. Reklam 4491'i Instagram'da olmak üzere toplam 4601 beğeni almıştır. Bu noktada hedef kitle geri bildirimlerini almada Instagram'1n daha etkili bir mecra olduğunu söylemek mümkündür.

\section{Trendyol Efsane Günler-Gülsel Birsel'in Gözünü Alamadı̆̆ı Fırsatlar}

Reklam mekânı bir ev olarak seçilmiştir. Reklamda ana karakter olarak Gülse Birsel görülmektedir. Tek başına yazacağı hikâyeye odaklanmaya çalışan bir yazar, pür dikkat bir şekilde bilgisayarında bir şeyleri yazıya geçirmenin peşindedir. Fakat odaklanma problemi ile karşı karşıyadır. Kafasını kurcalayan bir şeyler vardır. Bu yüzden kendini işine tam olarak verememektedir. Reklam boyunca kafasını kurcalayanın ne olduğunu bulmaya çalışan Gülse Birsel "Tamam ya işte bu" diyerek durumu çözer. O esnada diş ses devreye girer ve "Gülse Birsel'in aklından çıkaramadığg firsatlar cümlesini kullanarak tüm reklam boyunca yazarın odaklanma probleminin ana nedeninin Trendyol indirimleri olduğunu vurgular.

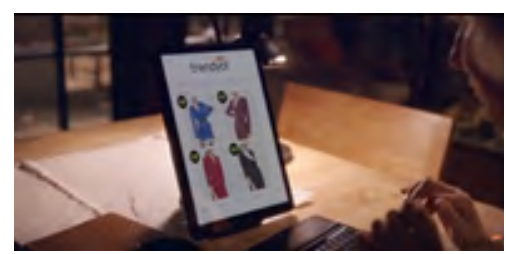

Gülse Birsel'in “İşte bu” diyerek bulduğu ürün kadın elbisesidir. Reklamın başından itibaren onu rahatsız eden şeyin aslında işine dair bir şey olduğu düşüncesi yaratılmaktadır, ancak aklını kurcalayan şey bir elbisedir. 

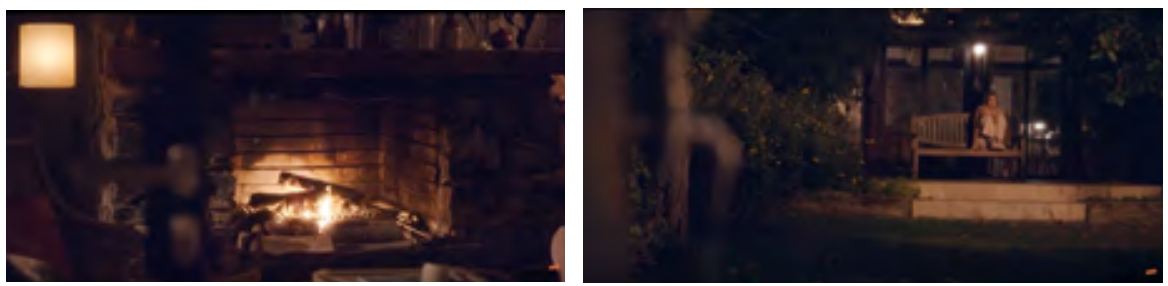

Reklamda Gülse Birsel oldukça rahat bir ortamdadır. $\mathrm{Bu}$ rahat ortamda bile kendisini rahat hissetmemektedir, huzursuz bir görüntü sergilemektedir. Aradığı elbiseyi Trendyol'da bulduktan sonra rahat bir yüz ifadesi kendisini göstermektedir. Bu noktada kültür endüstrisinin "tüketim sizi rahatlatır" vurgusu akla gelmektedir. Öyle ki tüketim bir kaçış, sorunlardan kurtulma yolu olarak yansıtılmaktadır. Tüketen, alışveriş yapan kişi böylece mutluluğa ulaşmaktadır.

Tablo 5. Gülse Birsel’in Gözünü Alamadığı Fırsatlar Reklamı Sosyal Medya Verileri

\begin{tabular}{|c|c|c|c|c|c|c|c|}
\hline & 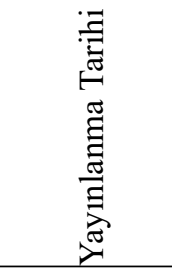 & 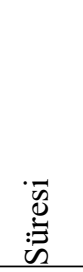 & 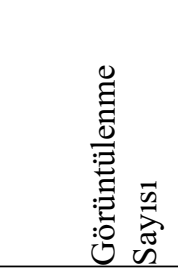 & 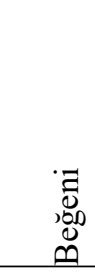 & 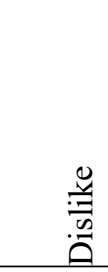 & $\underset{\partial}{\Xi}$ & 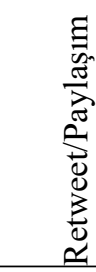 \\
\hline YOUTUBE & 21.11.2019 & $29 \mathrm{~s}$. & 79 bin & 17 & 41 & Kapalı & - \\
\hline INSTAGRAM & 21.11 .2019 & $29 \mathrm{~s}$. & 86 bin 47 & $\begin{array}{l}3 \text { bin } \\
385\end{array}$ & - & 57 & - \\
\hline TWITTER & 25.11 .2019 & $29 \mathrm{~s}$. & 2 bin 461 & 12 & - & 22 & 2 \\
\hline FACEBOOK & 21.11.2019 & $29 \mathrm{~s}$. & 8 bin 200 & 59 & 2 & 9 & 1 \\
\hline
\end{tabular}

Reklamın sosyal medya mecralarındaki görüntülenme sayısının en çok olduğu mecranın Instagram olduğu görülmektedir. İkinci sırada ise Youtube gelmektedir. Reklam tüm mecralarda toplam 175 bin görüntülenme sayısına ulaşmıştır. En çok beğeninin yine Instagram'da olduğu görülmektedir. Reklam toplamda 3473 beğeni almıştır. Bu noktada hedef kitle ve reklamveren etkileşiminin Instagram aracılığıyla daha fazla sağlandığını söylemek mümkündür. Hedef kitlenin en aktif olduğu mecra reklamverenlerin de aktif olmasinı gerektirmektedir.

\section{Trendyol Efsane Günler-Vedat Milor'un Gözünü Alamadı̆̆ı Fırsatlar}

Reklamda, ünlü gurme olan Vedat Milor'un bir program çekimi konu alınmaktadır. Vedat Milor'un iyi yemeklere düşkün imajı kullanılmıştır. Tabağı sunan kişi yemek sunumu karşısında bir eleştiri beklemektedir. Tabağı hazırlayan kişi hazırladığı yemek hakkında önemli bilgileri Vedat Milor'la paylaşmaktadır. Fakat Vedat Milor, telefonundan baktığ Trendyol indirimlerine dalmış durumdadır. Bulaşık deterjanı, karbonatlı diş macunu gibi ürünlere baktığ 1 için yemekle ilgili eleştiri bekleyen kişiye bu ürünlerden bahsetmektedir. 


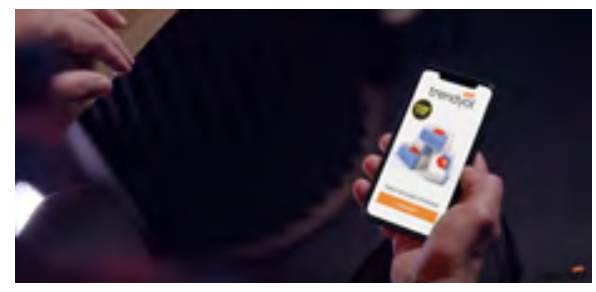

$\mathrm{Bu}$ ürünlerle birlikte hedef kitleye gündelik hayatta kullanılan kişisel bakım ürünleri ve hijyen ürünleri ürünlerin de Trendyol'un ürün yelpazesinde yer aldığı mesaj1 verilmiştir. Vedat Milor bu ürünlere bakarak daha sonrasında "\%50 diyorum, çok ciddi bir indirim" cümlesini kurarak indirimin büyüklüğüne dikkatleri çekmiştir ve hedef kitlede indirimin miktarını belirten bir konumlandırma gerçekleştirmektedir. Reklamın sonunda pardon diyerek asıl konusu olan yemeği eleştirecektir. Fakat sonrasında sunumu yapan kişi tekrar yemek hakkında bilgilerden bahsederken Vedat Milor tekrardan telefona dalmaktadır. Bireyin işinin bile önüne geçen indirim fırsatları olduğu algısı yaratılarak hedef kitle tüketime yönlendirilmektedir.

Tablo 6. Vedat Milor’un Gözünü Alamadığı Fırsatlar Reklamı Sosyal Medya Verileri

\begin{tabular}{|c|c|c|c|c|c|c|c|}
\hline & 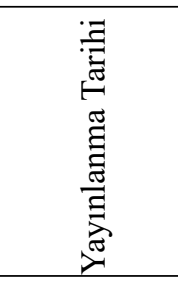 & 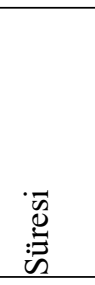 & 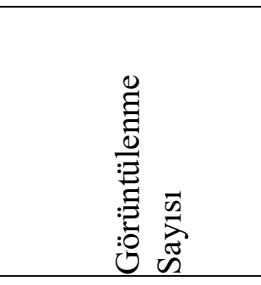 & $\begin{array}{l}\vec{D} \\
\text { D. } \\
\infty \\
\infty\end{array}$ & $\frac{\mathscr{v}}{\frac{\mathscr{n}}{\bar{n}}}$ & $\underset{\partial}{\Xi}$ & 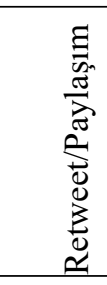 \\
\hline YOUTUBE & 21.11.2019 & $36 \mathrm{~s}$. & 1 milyon 700 bin & 35 & 17 & Kapalı & - \\
\hline INSTAGRAM & 21.11 .2019 & $36 \mathrm{~s}$. & 121 bin 89 & $\begin{array}{l}3 \text { bin } \\
757\end{array}$ & - & 145 & - \\
\hline TWITTER & 25.11.2019 & $36 \mathrm{~s}$. & 4 bin 20 & 6 & - & 67 & 0 \\
\hline FACEBOOK & 21.11 .2019 & 36 s.. & 9 bin 900 & 43 & 4 & 28 & 0 \\
\hline
\end{tabular}

Reklamın sosyal medya hesaplarındaki verilerine bakıldığında en çok görüntülenmenin Youtube'da olduğu görülmektedir. İkinci sirada ise Instagram bulunmaktadır. Reklam toplamda 1 milyon 835 bin görüntülenme sayısına ulamıştır. Dolayısıyla reklam kampanyanın diğer reklamlarından daha çok görüntülenmiştir. En çok beğeniyi ise Instagram'da alan reklam, toplamda 3841 beğeni almıştır.

\section{Sonuç}

Önceleri hayatın idame ettirilmesi için ihtiyaçların giderilmesine yönelik olan tüketim, özellikle modernizm ile birlikte bir hazza dönüşmüş, günümüzde ise bir yaşam biçimi haline gelmiştir. Bugün artık tüketmek insanoğlunun vazgeçilmez bir parçasıdır. Başlangıçtaki ihtiyaç nesnelerinin tüketimi yerini sembolik tüketime bırakmış, artık statü, kimlik, toplumsal bir var oluş için tüketme ve daha çok tüketme anlayışı oluşmuştur. Kitle iletişim araçları ise tüketimin yayılmasında ve artmasında dünden bugüne daima en etkili 
faktör olarak işlev görmüştür. 20. yüzyıl öncesinde geleneksel mecraların yürüttüğü bu işlev bugün yeni medya ortamları aracılığıyla yürütülür olmuştur.

İnternetin gelişmesine paralel olarak gelişen sosyal medya ortamları, tüketimin bireylere bir ihtiyaçmış gibi sunulması ve bireylerin tüketime yönlendirilmesi noktasında en etkili iletişim ortamları olarak karşımıza çıkmaktadır. İnternet teknolojilerinin gelişmesi fiziki mekânlarda alışveriş yapma mantığını da değiştirmiş, alışveriş sanal ortamlara taşınmıştır. Hızın ve pratik yaşamın çok önemli hale geldiği günümüzde internet ortamından alışveriş, bireylerin hayatını kolaylaştıran bir unsur olarak görülmektedir. Sanal mağazaların, sosyal medya ortamlarına entegre olarak reklam faaliyetlerini bu mecralarda yürütmeleri, bu ortamların avantajlarından yararlanmalarını, geleneksel mecralar aracılığıyla ulaşabilecekleri hedef kitle sayısının çok üstünde bir sayıya ulaşabilmelerini sağlamıştır. Bununla birlikte sosyal medyanın geri bildirim döngüsü sağlaması da reklamverenler açısından önemli bir avantajdır. Bu nedenle sosyal medya mecraları aracılığıyla sunulan ürün ve hizmetler tüketimin artmasını sağlamaktadır.

Çalışmada ele alınan reklamların tasarım dili açısından değerlendirmesi yapıldığında oyuncu tercihinin son dönemin popüler ünlülerinden yana olmasını, seçilen mekânları ve ünlülerin tercih ettiği ürünlerin farklı oluşunu tüketimi arttırmaya yönelik bir strateji olarak değerlendirmek mümkündür. Bunlar tesadüfi olmayan seçimlerdir. Tüketim kültürü, bireylere sürekli kimlik satın aldırmaktadır. Kampanya reklamlarında da "beğendiğiniz ünlünün aldığı ürünü alırsanız onun gibi olursunuz" algısı yaratılmaktadır. Ayrıca seçilen mekânların genellikle üst-orta sınıfın tercih ettiği yerler olması reklamlarda dikkati çeken bir başka noktadır. Bu mekânlara giden ünlüler de Trendyol'dan alışveriş yapmaktadır vurgusu ile Trendyol'dan alışveriş yapmanın bireylere statü kazandıracağı mesajı verilmektedir. Ayrıca her ünlünün farklı bir ürün satın alması da bilinçli yapılan bir hamledir. Böylece Trendyol'daki ürün çeşitliliğine dikkat çekilmiş ve başka bir siteyi ziyaret etmeye gerek olmadan bütün ürünlerin Trendyol'dan alınabileceği mesajı verilmiştir. Seçilen ünlülerin farklı meslek gruplarından olmaları da yine Trendyol'un herkese hitap ettiği fikrini yaratmaya yöneliktir.

Reklamlarda "Efsane indirimler için 25 Kasım'ı bekleyin” repliği ile yaratılan merak duygusu da bireyleri tüketime yönlendirmek için uygulanmış bir stratejidir. Çok büyük bir indirim olacakmış algısı yaratılarak bireylerin günü geldiğinde Trendyol'u ziyaret etmesi sağlanmaya çalışılmaktadır. Merak duygusunu gidermek için bile siteyi ziyaret eden bir kişinin ihtiyaç fazlası ürünleri satın alma olasılığı çok yüksektir. Dolayısıyla yapılan analizde, günümüzde sanal mağazalar ve sosyal medya ortamlarının tüketim kültürünün devamlılığını sağlayan önemli mecralar olduğu sonucuna varılmıştır. Kampanyanın sosyal medya mecralarında yapılan paylaşımlarındaki beğeni ve yorum sayıları dikkate alındığında sosyal medyanın sağladığı geri bildirim döngüsünün Trendyol reklamlarında da etkin bir şekilde işlediği belirlenmiştir. Firmanın böylece yaptığ1 reklam ve indirimlere ilişkin müşteri memnuniyetini ölçmesi, hem mevcut kampanyanın başarısını değerlendirme hem de gelecek dönem kampanyalarına yönelik strateji geliştirme noktasında fayda sağlaması mümkündür. 
Bu çalışma Trendyol'un Black Friday kampanyası ile sınırlıdır, ancak sosyal medya mecralarının ve sanal mağazacılık uygulamalarının tüketim kültürüne olan etkisini görmek adına tüketici davranışlarını merkeze alan çalışmalar yapmak da faydalı olacaktır.

\section{Kaynaklar}

Aykurt, Y. A. ve Şesen, E. (2017). "Social Media in Social Organization”, European Scientific Journal, 13(20), s. 1-22.

Baş, T. Ve Akturan, U. (2013). Sosyal Bilimlerde Bilgisayar Destekli Nitel Araştırma Yöntemleri, Ankara: Seçkin Yayıncılık.

Baudrillard, J. (2000). Tüketim Toplumu, Ferda Keskin ve Hazal Deliceçaylı (çev), İstanbul: Ayrıntı Yayınları.

Bauman, Z. (2006). Küreselleşme-Toplumsal Sonuçları, Abdullah Yılmaz (çev), İstanbul: Ayrıntı Yayınları.

Belk, R. W. (1995). “Studies in the New Consumer Behaviour”, Daniel Miller (ed), Acknowledging Consumption. London: Routledge, s.58-95.

Black Friday nedir, ne anlama geliyor? https://www.cnnturk.com/teknoloji/blackfriday-nedir-ne-anlama-geliyor, Erişim Tarihi: 01.02.2020.

Binark, M. (2012). "Yeni Medya ve Yaratıcı Endüstri”. Erdal Dağtaş (ed.), Medya Ekonomisi ve İşletmeciliği, Eskişehir: Anadolu Üniversitesi Açıköğretim Fakültesi Yayınları. s. 165-192.

Bocock, R. (1997). Tüketim, İrem Kutluk (çev), Ankara: Dost Yayıncılık.

Bottomore, R. (2016). Frankfurt Okulu ve Eleştirisi, Ümit Hüsrev Yolsal (çev), İstanbul: Say Yayınları.

Çakır, V. (2004). "Yeni İletişim Teknolojilerinin Reklam Üzerine Etkileri”, Selçuk İletişim Dergisi, 3(2), s. 168-181.

Çetinkaya, Y. (1992). Reklamcılık, İstanbul: Ağaç Yayınları.

Dağtaş, B. (2009). Reklam Kültür Toplum, Ankara: Ütopya Yayınları.

Davidson, M. (1992). The Consumerist Manifesto Advertising in Postmodern Times. Londra: Routlenge.

Dilmen, N. E. (2007). "Yeni Medya Kavramı Çerçevesinde İnternet GünlükleriBloglar ve Gazeteciliğe Yansımaları”, Marmara İletişim Dergisi, 12, s. 113-122.

Doğan, Ş. (2019). "Sosyal Medyanın Kamuoyu Oluşturmada Kullanımı: 16 Nisan 2017 Anayasa Değişikliği Referandumu Sürecinde Siyasi Aktörlerin Sosyal Medya Paylaşımlarının İçerik Analizi”, Erciyes İletişim Dergisi, 6(1), s. 423-442.

Eryentü, M. (2017). “Tüketim Kültürü Teorisi Bağlamında Çocukların Reklamlarda 
Konumlandırılış1: 'Koton Kids' Reklam Filmleri Üzerine Göstergebilimsel Bir İnceleme”, Folklor/Edebiyat, 23(91), s. 31-50.

Ewen, S. (1976). Captains of Consciousness, USA: McGraw-Hill.

Gackenbach, J. (2007). Psychology and The Internet: Intrapersonel, Interpersonel and Transpersonel Implications, San Diego: Elsevier Inc.

Güler, C. (2011). “Web 2.0: Blog, Wiki”. Mehmet Emin Mutlu (ed.), Yeni İletişim Teknolojileri, Eskişehir: Anadolu Üniversitesi Açıköğretim Fakültesi Yayınları, s. 50-72. Yayınları.

Harvey, D. (2010). Postmodernliğin Durumu, Sungur Savran (çev), İstanbul: Metis

İşlek, M. S. (2012). Sosyal Medyanın Tüketici Davranışlarına Etkileri: Türkiye'deki Sosyal Medya Kullanıcıları Üzerine Bir Araştırma. Yayımlanmamış Yüksek Lisans Tezi, KMÜ, Sosyal Bilimler Enstitüsü, Karaman.

Kadıoğlu, Z, K, (2014), Tüketim İletişimi (Süreçler, Algılar ve Tüketici), İstanbul: Pales Yayıncılık.

Kara, T. (2019). Sosyal Medya Endüstrisi, İstanbul: Beta Yayıncılık.

Kirtiş, K. A. ve Karahan, F. (2011). "To Be or Not To Be in Social Media Arena as The Most Cost-efficient Marketing Strategy After The Global Recession”, Procedia Social and Behavioral Sciences, 24, s. 260-268. Yayınları.

Lasch, C. (2006). Narsisizm Kültürü, Susan Öztürk (çev), Ankara: Bilim ve Sanat

Laughey, D. (2010). Medya Çalışmaları: Teoriler ve Yaklaşımlar. Ali Toprak (çev.). İstanbul: Kalkedon Yayınları.

Mattelart, A. (1994). Reklamcılık, Fatoş Ersoy (çev), İstanbul: Cep Üniversitesi İletişim Yayınları.

Murray, R. (1990). "Fordizm ve Post-Fordizm” Stuart Hall ve Martin Jacques (ed), Yeni Zamanlar, Abdullah Yılmaz (çev), İstanbul: Ayrıntı Yayınları, s. 46-63.

Odabaşı, Y. (2017). Postmodern Pazarlama, İstanbul: MediaCat Yayınları.

Özdemir, Z. (2015). "Sosyal Medyada Kimlik İnşasında Yeni Akım: Özçekim Kullanımı”, Maltepe Üniversitesi İletişim Fakültesi Dergisi, 2(1), 112-131.

Slater, D. (1997). Consumer Culture and Modernity, Cambrigde: Polity Press.

SI, S. (2016). "Social Media and Its Role in Marketing”, Business and Economics Journal, 7(1), s. 1-5.

Suğur, N. (1999). "Fordizm, Postfordizm ve Ötesi”, Anadolu Üniversitesi Edebiyat Fakültesi Dergisi, 1(1), s. 134-153.

Torlak, Ö. (2000). Tüketim: Bireysel Eylemin Toplumsal Dönüşümü, İstanbul: İnkılap Yayınları. 
Trust, R. ve Oliver, W. R. (1998). Notlar ve Yorumlar: Reklamcılığın Ölümü, Reklam, Halkla İlişkiler ve Ötesi, Ankara: MediaCat Yayınları.

Ünal, S. (2014). Göstergebilimsel Açıdan Sembolik Tüketim, Ankara: Detay Yayıncilik.

Vural, B. A. ve Bat, M. (2010). "Yeni Bir İletişim Ortamı Olarak Sosyal Medya: Ege Üniversitesi İletişim Fakültesine Yönelik Bir Araştırma”, Journal of Yaşar University, 20(5), s. 3348-3382.

Woodside, A.G. and Wilson, E.J. (2003). "Case Study Research Methods for Theory Building”, Journal of Business \& Industrial Marketing, 18(6/79, s. 493-508.

Yaylagül, L. (2008). Kitle İletişim Kuramları Egemen ve Eleştirel yaklaşımlar, Ankara: Dipnot Yayınları.

Yin, R. K. (1994). "Discovering the Future of the Case Study. Method in Evaluation Research”, Evaluation Practice, 15(3), s.283-290.

Yzer, M. C. ve Southwell, B.G. (2008). "New Communication Technologies, Old Questions", American Behavioral Scientist, 52(1), s. 8-20. 